\title{
SINKOP PADA PASIEN STROKE VERTEBROBASILER
}

\author{
Erupsiana Fitri ${ }^{1}$, Sri Sutarni ${ }^{2}$ \\ ${ }^{1}$ Residen Neurologi Fakultas Kedokteran, Universitas Gadjah Mada/ RSUP Dr. \\ Sardjito Yogyakarta \\ ${ }^{2}$ Bagian Neurologi Fakultas Kedokteran, Universitas Gadjah Mada/ RSUP Dr. \\ Sardjito Yogyakarta \\ Korespondensi: erupsiana@gmail.com
}

\begin{abstract}
ABSTRAK
Latar Belakang: Sinkop merupakan penyakit yang umum terjadi di masyarakat. Sinkop adalah kehilangan kesadaran sementara dengan awitan akut yang diikuti dengan jatuh, dan pemulihan spontan sempurna tanpa intervensi. Sinkop merupakan gejala dari suatu penyakit sehingga harus dicari etiologinya. Salah satu penyebab sinkop adalah kelainan sentral atau neurologis berupa insufisiensi vertebrobasiler, TIA, dan kelainan jantung.

Tujuan: mengetahui bahwa sinkop adalah sebuah gejala penyakit yang harus dicari penyebabnya, karena bisa berakibat kematian.

Kesimpulan: sinkop adalah salah satu tanda stroke infark yang berkaitan dengan jantung.
\end{abstract}

Kata Kunci: sinkop, stroke infark, gangguan jantung 


\title{
SINKOP PADA PASIEN STROKE VERTEBROBASILER
}

\author{
Erupsiana Fitri ${ }^{1}$, Sri Sutarni ${ }^{2}$ \\ ${ }^{1}$ Neurology Resident Medical Faculty, Universitas Gadjah Mada/ Sardjito Central \\ Hospital Yogyakarta \\ 2Departement of Neurology Medical Faculty, Universitas Gadjah Mada/ Sardjito \\ Central Hospital Yogyakarta \\ Corespondence: erupsiana@gmail.com
}

\begin{abstract}
Background: Syncope is a common disease in the community. Syncope is a temporary loss of consciousness with an onset followed by a perfect, spontaneous fall without perfect intervention. Syncope is a symptom of acid disease should be sought etiologinya. One of the causes of syncope is a central or neurological disorder of vertebrobacillary insufficiency, TIA, and heart abnormalities.

Aim: knowing that syncope is a symptom of disease that must be sought cause, because it can result in death

Conclusion: syncope is one of stroke symptoms which has relation with heart.
\end{abstract}

Keyword: syncope, stroke infraction, heart abnormalities. 


\section{PENDAHULUAN}

Sinkop atau pingsan merupakan permasalahan yang penting dewasa ini. Secara substansial mengakibatkan pe-nurunan kualitas hidup pada semua dimensi kesehatan terutama mobilitas, aktivitas sehari-hari, dan perawatan diri sendiri. ${ }^{1}$

Sinkop digambarkan sebagai masalah yang relatif kompleks dan seringkali berpotensi membahayakan, kadang- kadang manifestasi klinis tidak jelas. Studi prospektif 1 tahun terakhir terhadap pasien sinkop menunjukkan mortalitas yang tinggi, kematian mendadak ditemukan berkisar antara 3-24\% dalam 1 tahun. Kematian berlebih ditemukan pada pasien dengan kelainan kardiovaskular yang mendasari. 2

Sinkop adalah T-LOC (transient loss of consciousness) yang disebabkan karena hipoperfusi serebral global sementara yang ditandai dengan onset cepat, durasi pendek, dan pemulihan lengkap spontan. Definisi sinkop ini berbeda dengan definisi lainnya, karena memasukkan penyebab ketidaksadaran, yaitu hiperplantasi serebral global sementara. ${ }^{3}$

Sinkop merupakan salah satu penyebab penurunan kesadaran yang banyak ditemukan di Unit Gawat Darurat (UGD). Sinkop didefinisikan sebagai hilangnya kesadaran sesaat, dengan kehilangan postur tubuh (jatuh). Merupakan 3\% dari kunjungan UGD dan 6\% dari kunjungan rawat jalan ke rumah sakit. Mengatasi penyebab pingsan lainnya sangat penting karena prognosis dan pengobatannya berbeda. ${ }^{4}$ Sinkop merupakan gejala suatu penyakit sehingga harus dicari etiologinya. 5

Dalam studi berbasis populasi didapatkan prevalensi sinkop pada pria sama dengan wanita, kejadiannya hampir 2 kali lipat pada pasien dengan riwayat kardiovaskular. Kematian sekitar 30\% lebih tinggi pada sinkop yang tidak diketahui sebabnya. ${ }^{6}$

\section{LAPORAN KASUS}

Laki-laki usia 67 tahun, seorang pegawai swasta, datang dengan post sinkop. Terdapat kelemahan anggota gerak kanan, paresis N. VII (S) UMN dan paresis $\mathrm{N}$ XII (S) UMN. Wanita usia 57 tahun, seorang ibu rumah tangga, datang dengan dizziness akut, dengan riwayat penyakit jantung, diabetes mellitus dan vertigo. Terdapat nistagmus horizontal fase cepat ke kiri dan hiperkolesterolemi.

\section{PEMBAHASAN}

\section{Epidemiologi}

Sinkop sering dijumpai, dan sangat penting untuk melakukan evaluasi klinis pada praktek medis. Dalam hal kunjungan ke rumah sakit, sinkop mencapai 3\% kunjungan ruang gawat darurat dan $1 \%$ - 6\% dari kunjungan pasien umum di rumah sakit Amerika Serikat. Minimal 3\% populasi mengalami sinkop selama pengamatan 25 tahun. ${ }^{7}$

Sinkop relatif sering terjadi di semua kelompok usia, mulai dari $15 \%$ anak usia di bawah 18 tahun dan $23 \%$ pada pasien lansia berusia di atas 70 tahun. Prevalensi dan kejadian sinkop meningkat seiring bertambahnya usia, dengan 30\% tingkat kekambuhan. ${ }^{4}$

Penelitian di Irlandia menyatakan kunjungan pasien sinkop murni sebesar $1,1 \%$ dari seluruh kunjungan ke UGD. Di Amerika Serikat prevalensi $19 \%$ penduduk mngalami sinkop, dengan karakteristik usia > 75 tahun (21\%) dan 45-54 tahun $(20 \%)$, laki-laki dibanding perempuan $15 \%$ : $22 \% .8$

Sinkop umum terjadi pada populasi masyarakat dan episode 
pertama muncul pada karakteristik usia yang ditunjukkan oleh Gambar 1. Prevalensi sangat tinggi untuk sinkop pada pasien 10 - 30 tahun, dengan puncak $47 \%$ pada wanita dan $31 \%$ pada pria berusia sekitar 15 tahun. ${ }^{3}$

\section{Etiologi}

Sinkop merupakan gejala, bukan penyakit, dan dapat diklasifikasikan sesuai dengan penyebabnya antara lain karena gangguan neurologis, metabolik, psikiatri, dan jantung. ${ }^{4}$ Sinkop karena kelainan jantung merupakan bentuk yang paling umum, meliputi sinkop karena penyakit jantung mekanis atau struktural, aritmia jantung, dan sinkop neurokardiogenik.

Sinkop neurokardiogenik disebabkan oleh respons otonom yang tidak normal atau berlebihan terhadap berbagai rangsangan contah berdiri dan emosi. Mekanisme pasti kurang dipahami, tetapi melibatkan refleks yang dimediasi oleh perubahan denyut jantung atau suara jantung, disebabkan oleh aktivasi serat $\mathrm{C}$ jantung. Sinkop neurokardiogenik ditandai dengan hipotensi atau bradikardi yang dimediasi oleh baroreseptor terhadap tekanan ortostatik. ${ }^{9}$

Tabel 1. Klasifikasi patofisiologis penyebab utama sinkop

\begin{tabular}{|c|c|c|c|c|c|c|c|}
\hline \multicolumn{2}{|c|}{$\begin{array}{c}\text { Reflek sinkop } \\
\text { (terkait neurologi) }\end{array}$} & \multicolumn{3}{|c|}{$\begin{array}{c}\text { Sinkop karena hipetensi } \\
\text { orthostatic }\end{array}$} & \multirow{2}{*}{ 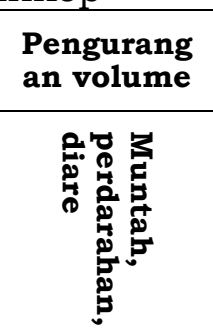 } & \multicolumn{2}{|c|}{$\begin{array}{c}\text { Drug induced } \\
\text { bradicardi dan } \\
\text { takiaritmia }\end{array}$} \\
\hline 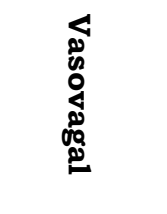 & 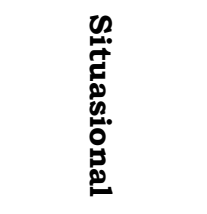 & 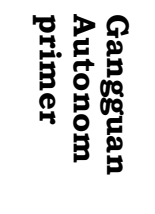 & 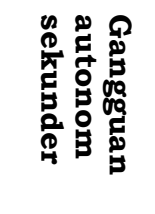 & 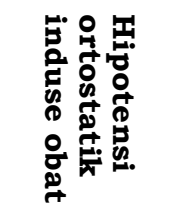 & & 号 & 苞. \\
\hline $\begin{array}{l}\text { Pencetus: } \\
\text { stress } \\
\text { emosiona } \\
\text { 1, sedih, } \\
\text { nyeri, } \\
\text { phobia } \\
\text { darah, } \\
\text { dan } \\
\text { pemakai } \\
\text { nan alat } \\
\text { musik }\end{array}$ & $\begin{array}{l}\text { Flu dan } \\
\text { bersin }\end{array}$ & $\begin{array}{l}\text { Murni } \\
\text { ganggua } \\
\mathrm{n} \\
\text { aotonom } \\
\text { ' multiple } \\
\text { atrofi } \\
\text { system, } \\
\text { Parkinso } \\
\text { n's } \\
\text { dengan } \\
\text { ganggua } \\
\text { n } \\
\text { aotonom }\end{array}$ & $\begin{array}{l}\text { DM, } \\
\text { amiloido } \\
\text { sis, } \\
\text { uremik, } \\
\text { trauma } \\
\text { spinal }\end{array}$ & $\begin{array}{l}\text { Alcohol, } \\
\text { vasodilato } \\
\text { r, } \\
\text { diuretic, } \\
\text { phenotiaz } \\
\text { id, } \\
\text { antidepre } \\
\text { san }\end{array}$ & $\begin{array}{l}\text { Sinkop } \\
\text { kardiogenik }\end{array}$ & $\begin{array}{l}\text { Penyakit } \\
\text { katup } \\
\text { jantung, } \\
\text { AMI, } \\
\text { tampono } \\
\text { de, } \\
\text { penyakit } \\
\text { pericardi } \\
\text { al, dan } \\
\text { disfungs } \\
\text { katup } \\
\text { buatan. }\end{array}$ & $\begin{array}{l}\text { emboli } \\
\text { paru, } \\
\text { diseksi } \\
\text { aorta } \\
\text { akut, } \\
\text { dan } \\
\text { hiperte } \\
\text { nsi } \\
\text { pulmon } \\
\text { al }\end{array}$ \\
\hline $\begin{array}{l}\text { Stress } \\
\text { ortostatik }\end{array}$ & $\begin{array}{l}\text { Stimulasi } \\
\text { gastrointest } \\
\text { inal } \\
\text { Post } \\
\text { exercise }\end{array}$ & & & & $\begin{array}{l}\text { Penyebab } \\
\text { primer } \\
\text { aritmia: } \\
\text { Bradikardi: } \\
\text { disfungsi } \\
\text { sinus node, } \\
\text { atrioventric } \\
\text { ular } \\
\text { conduction } \\
\text { system } \\
\text { disease } \\
\text { Takikardi: } \\
\text { SVT, } \\
\text { ventrikuler } \\
\text { Muntah, } \\
\text { perdarahan } \\
\text {, diare }\end{array}$ & & \\
\hline
\end{tabular}

Sumber : (Moya et al., 2009) 


\section{Manifestasi Klinis}

Sinkop tanpa riwayat defisit neurologi ataupun defisit neurologis berulang, seperti pada penyakit Stigmata kardiovaskular, koroner, atau penyakit kardiovaskular berulang lainnya, tidak terkait dengan peningkatan morbiditas atau mortalitas. Sinkop sekunder akibat non kardiovaskular atau tidak diketahui penyebabnya tidak berisiko meningkatkan kematian mendadak jika tidak memiliki penyakit mendasar yang mengancam jiwa. Studi menunjukkan bahwa sinkop merupakan gejala paling sering pada penyakit serebrovaskular dan merupakan faktor risiko stroke. Tiga kategori utama sinkop berdasarkan patofisiologi antara lain: 1) Penurunan aliran darah serebral akut, seperti pada sinkop vasovagal, gangguan jantung, penyumbatan pembuluh darah paru dan obstruksi aliran balik, kegagalan pengembalian vena, nadi tidak teratur, dan atau penyakit serebrovaskular, 2) Gangguan peredaran zat yang mengalir ke otak, seperti pada hipoglikemia, hypocapnea, atau hipoksia, 3) Penyebab saraf dan atau psikologi seperti pada kejang nonkonvensional, histeria, atau jenis serebral sinkop sinus karotis.

Kategori penurunan akut aliran darah pada umumnya, dan reflek vasovagal secara khusus, mungkin merupakan proporsi terbesar dari kejadian sinkop. ${ }^{2}$

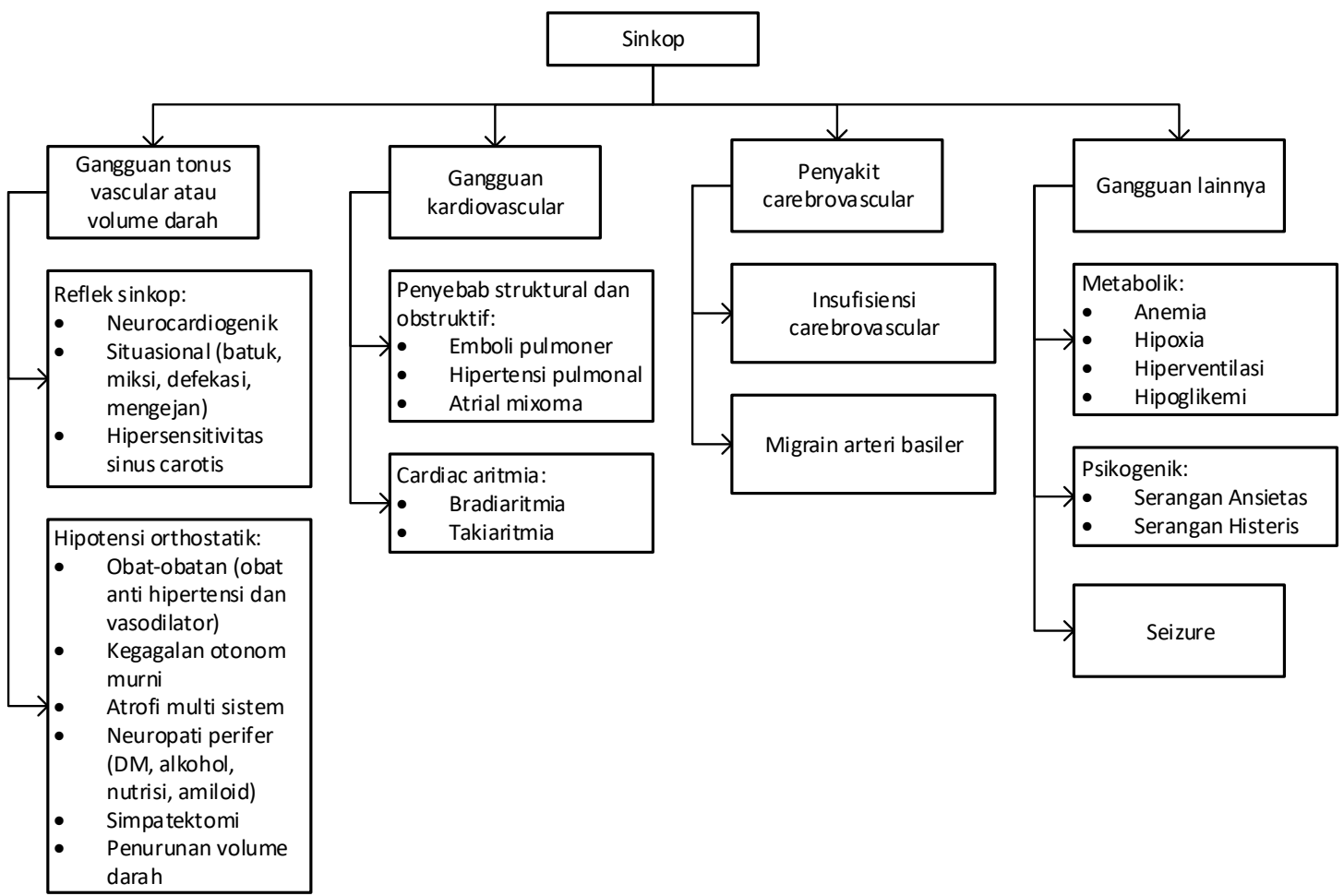

Gambar 1. Penyebab Sinkon (sumber: Moya et al,2009)

Sinkop adalah kehilangan kesadaran secara mendadak, beberapa detik atau menit, disebabkan otak tidak mendapatkan cukup oksigen. ${ }^{5}$ Terdapat penurunan aliran darah otak, pengisian oksigenasi serebral disertai resistensi serebrovaskuler. Jika iskemia berlangsung beberapa menit, maka tidak menyebabkan kelainan otak. Iskemia yang lama mengakibatkan nekrosis jaringan otak, daerah 
perbatasan perfusi antara daerah vaskuler arteri serebralis mayor. ${ }^{10}$

Patofisiologi sinkop terdiri dari

3 tipe: (1) Penurunan output jantung sekunder seperti pada penyakit jantung intrinsik atau terjadi penurunan klinis volume darah yang signifikan. (2) Penurunan resistensi pembuluh darah perifer dan atau venous return. (3) Penyakit serebrovaskular yang berat mengarahkan pada penurunan perfusi serebral. Gangguan oksigenasi otak yang cukup mengakibatkan perubahan kesadaran sementara.

Stroke adalah suatu penyakit yang ditandai dengan gejala dan atau tanda klinis yang berkembang dengan cepat berupa gangguan fungsional otak fokal maupun global berlangsung lebih dari 24 jam, kecuali ada intervensi bedah atau membawa kematian, tidak disebabkan oleh sebab lain selain penyebab vaskuler. Definisi ini mencakup stroke akibat infark otak (stroke iskemik), perdarahan intraserebral non traumatik, perdarahan intraventrikuler dan beberapa kasus perdarahan subarakhnoid. ${ }^{11}$

Stroke iskemik adalah stroke yang timbul akibat trombosis atau embolisasi yang terjadi dan mengenai pembuluh darah otak menyebabkan obstruksi aliran darah otak yang mengenai satu atau lebih pembuluh darah. Stroke iskemik akut adalah gejala klinis defisit serebri fokal dengan onset yang cepat dan berlangsung lebih dari 24 jam dan dapat menyebabkan kematian. Oklusi pembuluh darah disebabkan oleh proses trombosis atau emboli yang mengakibatkan iskemia fokal atau global. Oklusi ini mencetuskan serangkaian kaskade iskemik yang menyebabkan kematian sel neuron atau infark serebri. Aliran darah otak akan menurun sampai mencapai titik tertentu yang seiring dengan gejala kelainan fungsional, biokimia dan struktural dapat menyebabkan kematian sel neuron yang permanen (irreversibel). ${ }^{12}$

Stroke adalah penyebab kematian ke-3 terbesar di negara maju setelah penyakit jantung koroner dan kanker. Mortalitas stroke selama 30 hari pada tahun pertama adalah $20 \%$ dan 30\%.13

\section{Penegakan Diagnosis}

(1) Anamnesis dan Pemeriksaan Fisik. Sinkop terjadi akibat berkurang-nya perfusi darah diotak. Penting sekali diketahui riwayat kejadian saat sebelum terjadi sinkop untuk menentukan penyebab serta menyingkirkan diagnosis banding yang ada. Dari anamnesis harus ditanyakan riwayat pasien secara teliti dan seksama, sehingga dapat menggambarkan kemungkinan penyebab sinkop atau dapat sebagai petunjuk untuk strategi evaluasi pasien.

Gambaran klinis yang muncul pada setiap pasien sangat penting untuk diketahui terutama faktorfaktor yang dapat merupakan predisposisi terjadinya sinkop beserta akibatnya. ${ }^{5}$ Harus dilakukan pemeriksaan fisik lengkap saat di IGD. Perhatian khusus harus diberikan pada aspek tertentu dari pemeriksaan fisik pasien datang dengan sinkop. ${ }^{5}$ (2) Analisis tandatanda vital, tekanan darah dan nadi pada posisi berbaring dan berdiri. (3) Auskultasi arteri subklavia dan arteri karotis. (4) Pemeriksaan jantung lengkap dapat memberikan gambaran mengenai etiologi sinkop. (5) Pemeriksaan neurologis cermat sebagai barometer perbaikan ataupun perburukan gejala. Status mental biasanya normal. (6) Identifikasi trauma Pemeriksaan Neurologi. ${ }^{5}$ (7) Disfungsi otonom. Sistem saraf otonom yang tidak mampu menyesuaikan perubah-an posisi menyebabkan hipotensi 
ortostatik dan sinkop. Derajat sinkop didasarkan pada lamanya pasien berdiri sebelum akhirnya duduk. Impotensi dan gangguan miksi merupakan jenis disfungsi otonom lainnya. (8) Test mengangkat kepala. Pasien posisi berbaring kemudian diberikan provokasi untuk mendiagnosis sinkop vasodepressor. Provokasi tersebut dengan pengangkatan kepala hingga mencapai sudut maksimum 60-70. Biasanya akan mencetuskan hipotensi simtomatik atau sinkop dalam waktu 10-30 menit.

\section{Tata Laksana}

Manajemen Terapi Fisik, sebelumnya diyakini bahwa auto regulasi otak terjadi pada tingkat arteriolar serebral sebagai respons terhadap tekanan sistemik. Vaskularisasi arteriol dan vasokonstriksi terjadi selama penurunan dan peningkatan tekanan darah sistemik. Autoregulasi serebral abnormal bertanggung jawab atas hilangnya kesadaran pada pasien dengan sinkop neuro-kardiogenik. Hemodinamik serebral yang abnormal terjad secara signifikan selama kemiringan kepala tegak pada anak-anak dengan kelainan neurokardiogenik. ${ }^{14}$

\section{Prognosis}

Sinkop dengan etiologi kelainan kondisi jantung prognosis buruk. ${ }^{5}$ Sinkop nonkardiak tampaknya tidak berpengaruh pada tingkat kematian dan termasuk sinkop karena respon vasovagal, insufisiensi otonom, situasi, dan posisi ortostatik. 15

Sinkop Vasovagal dan sinkop ortostatik memiliki prognosis yang baik, tidak meningkatkan angka kematian, dan jarang kambuh. Sinkop vasovagal dan sinkop ortostatik tidak meningkatkan risiko kematian, namun kadang kambuh dan kadang-kadang menjadi sumber morbiditas yang signifikan dalam hal kualitas hidup dan cedera sekunder. 15

Etiologi sinkop yang tidak diketahui umumnya memiliki prognosis baik, dalam 1 tahun menunjukkan kejadian kematian mendadak rendah $(2 \%)$, kemungkinan $20 \%$ sinkope akan berulang, dan tingkat remisi $78 \% .{ }^{15}$

\section{Kasus 1}

Seorang laki- laki, 67 tahun, seorang pegawai swasta dengan pendidikan tidak sekolah, dikonsulkan ke bagian Saraf RSUP dr. Sardjito dengan adanya keluhan sering pingsan sejak 2 minggu sebelum masuk rumah sakit. Sebelum pingsan pasen mengeluhkan adanya keluhan nggliyer diikuti dengan pandangan gelap. Disangkal adanya mual, muntah, gangguan pendengaran, gangguan telinga, kelemahan sesisi, pelo, perot, nyeri kepala, pandangan dobel/kabur, gangguan perilaku, gangguan memori, kejang, demam, trauma, penurunan berat badan, dan gangguan otonom. Riwayat dilakukan pemasangan PCI 2 minggu yang lalu. Riwayat diabetes Melitus sejak lebih dari 5 tahun yang lalu. Disangkal Riwayat hipertensi

Pada pemeriksaan fisik tanda vital dan status interna didapatkan adanya kardiomegali, lain-lain dalam batas normal. Pada status neurologis didapatkan; Kondisi umum: sedang, kesadaran: compos mentis. Kepala: pupil isokor, $\Phi 3 \mathrm{~mm} / 3 \mathrm{~mm}, \mathrm{RC}+/+$, $\mathrm{RK}+/+$. Nn Cranialis: dbn. Nistagmus horizontal bilateral bidirectional.

Ekstremitas:

Gerak bebas terbatas pada ekstremitas dekstra, kekuatan 4+ pada ekstremitas dekstra, reflek fisiologis +2 pada ke empat ekstremitas, reflek patologis negatif pada kempat ekstremitas, clonus negatif pada keempat ekstremitas dektra. Pemeriksaan laboratorium, leukosit 15810, hemoglobin 10,2, 
hematokrit 30,0, neutrofil $88,5 \%$, GDS 164, creatinin 2,26. hasil laboratorium lain dalam batas normal. Hasil rontgen thorax PA didapatkan gambaran cardiomegali dan pulmo dalam batas normal. CT
Scan kepala potongan axial, koronal, dan sagital.didapatkan gambaran atrofi cerebri, old infark di lobus frontoparietalis kanan, ortikal infark dilobus temporalis kanan, sinusitis splenoidalis kiri.

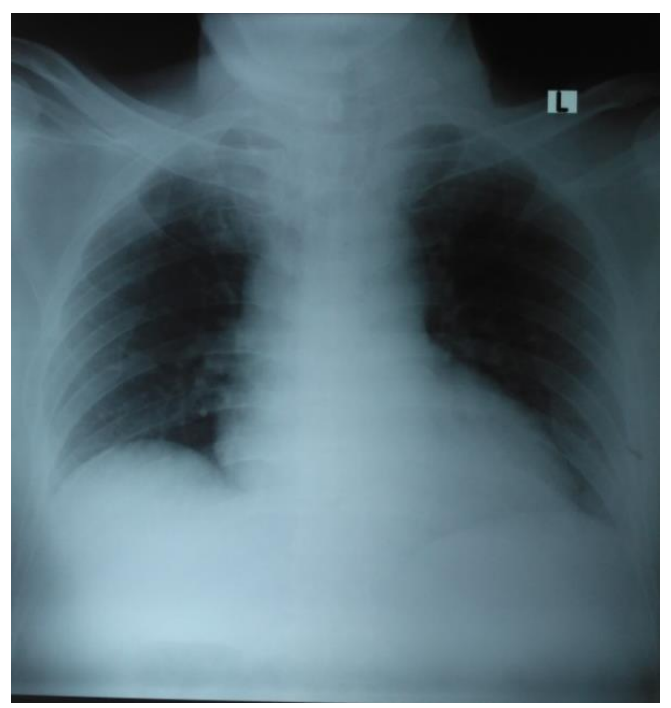

Gambar 2. Rongen Thorax PA:
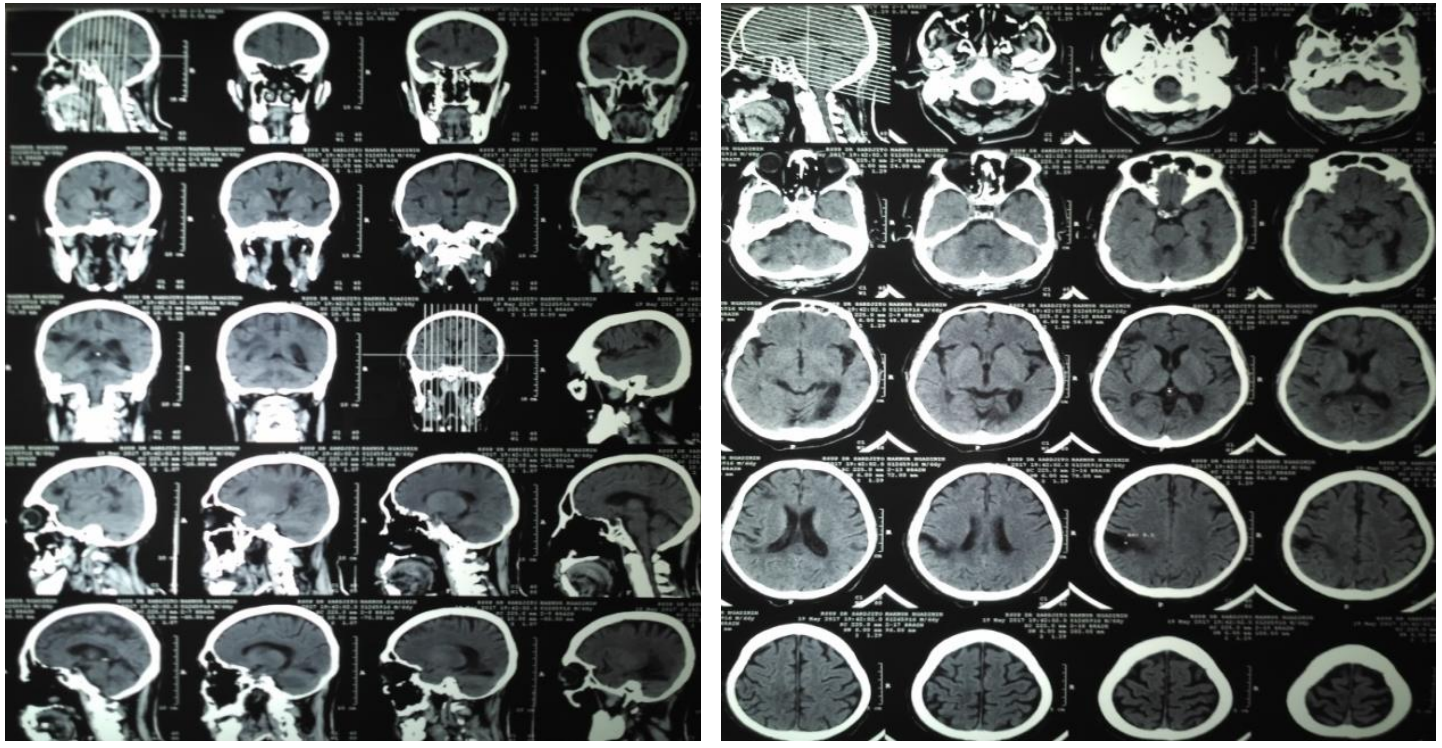

Gambar 3. CT Scan Kepala: Potongan axial, koronal, dan sagital.

\section{Kasus 2}

Seorang wanita 57 tahun dengan dizziness akut, intensitas ringan, hilang timbul, muncul saat bergerak dan perubahan posisi, berkurang dengan istirahat, disertai pandangan kabur. Disangkal mual, muntah, telinga berdenging sebelumnya, nyeri telinga, kelemahan anggota gerak, pelo perot, tersedak, gangguan perilaku, gangguan daya ingat dan kesemutan sesisi. Riwayat unstable angina pectoris, coronary artery disease 5 hari yang lalu, gagal jantung sejak 3 tahun yang lalu, Diabetes Melitus 
sejak 12 tahun yang lalu, dan vertigo 5 tahun yang lalu.

$$
\text { Pada pemeriksaan fisik }
$$
didapatkan vital sign dalam batas normal dan status interna didapatkan adanya kardiomegali, lainlain dalam batas normal. Kondisi umum: lemah, compos mentis. Kepal: pupil isokor $3 \mathrm{~mm} / 3 \mathrm{~mm}, \mathrm{RC}(+/+)$, RK $(+/+)$, DEP $(+) . \quad$ N. cranialis dalam batas normal. Nistagmus horisotal fase cepat ke kiri.
Ekstremitas: Gerak normal pada 4 ektremitas, kekuatan 5 , reflek fisiologis +1 di 4 ekstremitas, tidak didapatkan refek patologis, tidak didapatkan klonus. Pemeriksaan laboratorium didapatkan hipergliemi 224 hasil laboratorium lain dalam batas normal. Hasil rontgen thorax PA didapatkan gambaran cardiomegali dan pulmo dalam batas normal. CT Scan kepala potongan axial, koronal, dan sagital didapatkan gambaran dalam batas normal.

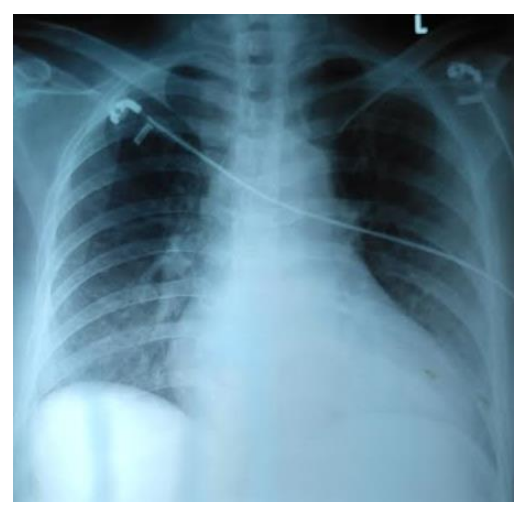

Gambar 4. Rongen Thorax PA: Cardiomegali dan pulmo dalma batas normal.

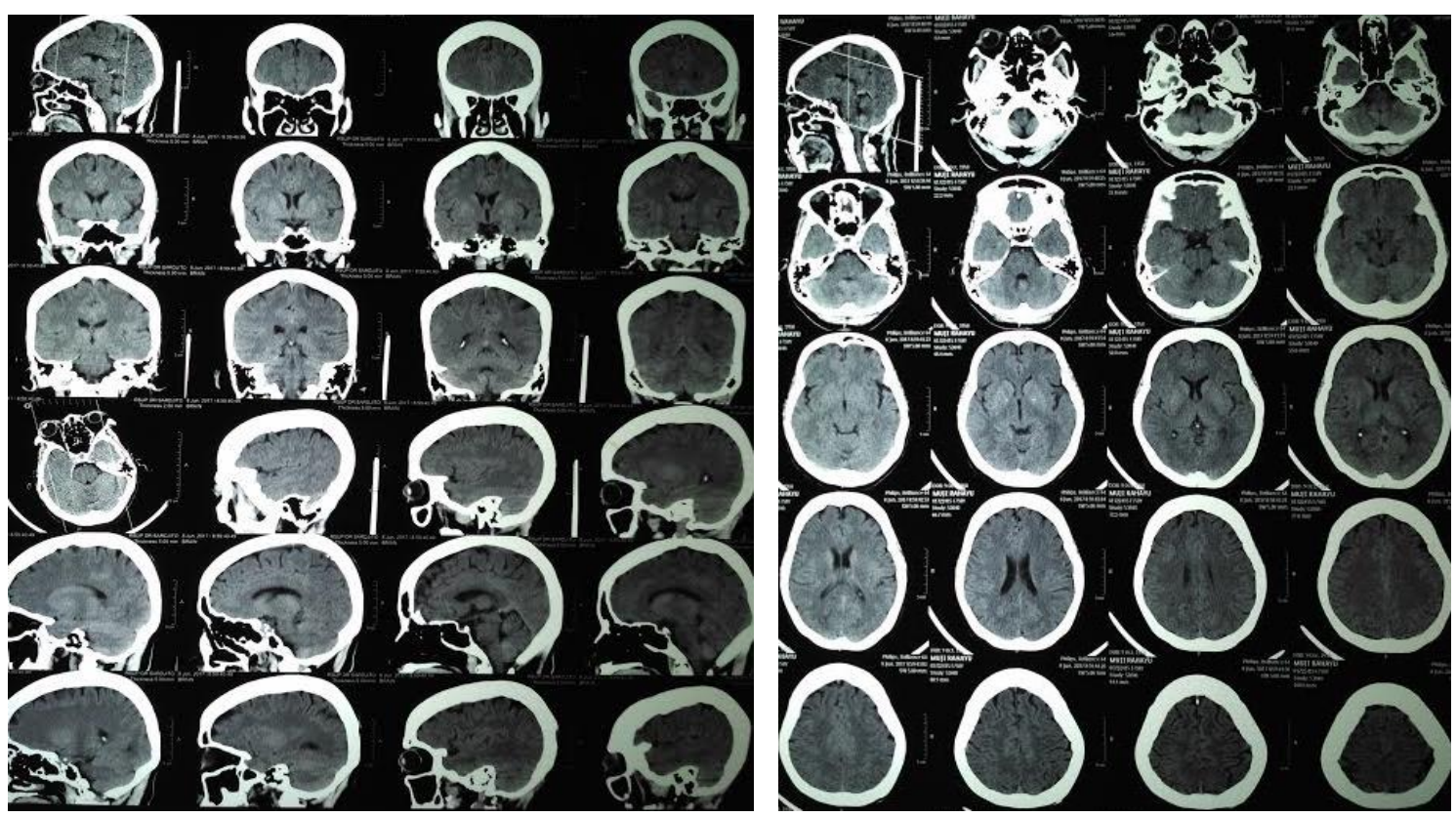

Gambar 5. CT Scan Kepala potongan axial, koronal, dan sagital: Tanpa kontras dalam batas normal 


\section{DAFTAR PUSTAKA}

1. Sheldon, R, Rose, S and Connolly, S. Prevention of Syncope Trial (POST), A Randomized, PlaceboControlled Study of Metoprolol in the prevention of Vasovagal Syncope. The European Society of Cardiology.

http:// europace.oxfordjournals.or g/content/5/ 1/71.full.pdf. 2006.

2. Savage, D.D., Corwin, L., Kannel, W.B.,. Epidemiologic features of isolated syncope: the Framingham Study. Stroke; a journal of cerebral circulation, 1985. 16(4), pp.626-629.

3. Moya, A., Sutton, R., Ammirati, F., Guidelines for the diagnosis and management of syncope (version 2009). European Heart Journal, 2009. 30(21), pp.26312671.

4. Downward, J., 2004. Clinical review. October, 329 (October 2006), p.2004.

5. Fauci, AS., Braunwald, Kasper. Harrison's Principles of Manual Medicine 17th Edition. New York : McGraw-Hill's Access Medicine. Hal : 207-211

6. Sample, S., The Ne $w$ Eng $\mathrm{l}$ a nd Jo u r n a l of Me dic i ne Incidence And Prognosis fF Syncope., 2002. 347(12), pp.878-885.

7. Benditt, D.G., Ferguson, D. W., Grubb, B. P., Tilt table testing for assessing syncope. Journal of the American College of Cardiology, 1996. 28(1), pp.263-275.

8. McCarthy, $\mathrm{F}$ et all, Management of syncope in the Emergency Department: a single hospital observational case series based on the application of European Society of Cardiology Guidelines.
European Society of Cardiology. http:// europace.oxfordjournals.or g/content/5/1/216.full.pdf. 2008

9. Ward, C.R., Gilroy, J.J., Gray, J.C., Midodrine: a role in the management of neurocardiogenic syncope. Heart (British Cardiac Society), 79(1), 1998. pp.45-9. Available at: http://www.pubmedcentral.nih.g ov/articlerender.fcgi?artid= $1728578 \&$ tool $=$ pmcentrez\&render type $=$ abstract.

10. Ooi S, Peter M. Guide To The essentials in emergency Medicine. National University Hospital. Mc Graw Hill. 2008. Hal :140-143

11. Warlow CP, Dennis MS, van Gijn JC, Stroke: A Practical Guide to Management. First. London: Blackwell Science. 2007

12. Gofir A, Manajemen Stroke. 2nd ed. Yogyakarta: Pustaka Cendekia Press. 2011

13. Scherbakov N, Doehner W, Sarcopenia in stroke facts and numbers on muscle loss accounting for disability after stroke. J Cachexia Sarcopenia Muscle. Mar; 2(1):5-8. 2009

14. Kosinski, D., Grubb, B.P. \& Temesy-Armos, P., Pathophysiological aspects of neurocardiogenic syncope: current concepts and new perspectives. Pacing and clinical electrophysiology: PACE, $18(4 \mathrm{Pt}$ 1), pp.716-24. Available at: http://www.ncbi.nlm.nih.gov/pu bmed/7596855. 1995

15. Morrag, Rum. Syncope. Medscape Reference. 2014. Available at: $h t t p: / /$ emedicine. medscape .com/article/811669overview. Tanggal 11 April 2015 